\title{
Pengaruh Penambahan Tepung Daun Bayam Dalam Pakan Komersil Terhadap Pertumbuhan Kepiting Bakau (Scylla serrata) Yang Dipelihara Dengan Sistem Resirkulasi Tertutup
}

\author{
[The Effect of Feeding with Commercial Feed contained Spinach Leaf Meal on the Growth \\ of Mud Crab (S. serrata) Reared in Closed Recirculation System]
}

\author{
Edi $^{1}$, Wellem. H Muskita ${ }^{1}$, Oce Astuti ${ }^{1}$, Agus Kurnia ${ }^{1}$, Muhaimin Hamzah ${ }^{1}$, Yusnaini ${ }^{1}$ \\ ${ }^{1}$ Program Studi Budidaya Perairan, Faluktas Perikanan dan Ilmu Kelautan Universitas Halu Oleo \\ Jl. HAE Mokodompit Kampus Bumi Tridharma Anduonohu Kendari, Indonesia 93232 \\ Email korespondensi : edildc55@gmail.com
}

\begin{abstract}
ABSTRAK
Penelitian ini bertujuan untuk mengetahui pengaruh pemberian pakan buatan dengan tepung daun bayam (TB) dalam pakan komersial (PK) terhadap pertumbuhan dan kelangsungan hidup kepiting bakau (S. serrate) yang dipelihara dengan sistem resirkulasi tertutup. Penelitian ini menggunakan rancangan acak lengkap (RAL) dengan 4 perlakuan dan 3 ulangan. Terdapat empat jenis pakan buatan dengan presentase yang berbeda PK 55\% TB 40\% B 5\% (Pakan A), PK 50\% TB 45\% B 5\% (Pakan B), PK 45\% TB 50\% B 5\% (Pakan C) dan PK 40\% TB 55\% B 5\% (Pakan D) diberikan kepada kepitng bakau selama 60 hari. Parameter yang diamati adalah pertumbuhan mutlak (PM), laju pertumbuhan spesifik (LPS) dan kelangsungan hidup (SR.). Hasil penelitian menunjukan bahwa nilai rata-rata pertumbuhan mutlak berkisar antara 17,3 - 22,3 g sedangkan nilai rata-rata laju pertumbuhan spesifik pada kepiting bakau yang diberikan pakan uji berkisar antara 0,0025-0,0038\% dan nilai rata-rata kelangsungan hidup kepiting bakau yaitu $100 \%$. Hasil analisa sidik ragam menunjukan pakan buatan dengan penambahan tepung bayam memberikan pengaruh yang tidak signifikan $(\mathrm{P}>0,05)$ terhadap pertumbuhan mutlak, laju pertumbuhan spesifik dan kelangsungan hidup. Peneitian ini menyimpulkan bahwa tepung daun bayam dapat ditambahkan pada pakan buatan berkisar 40-50\%.
\end{abstract}

Kata kunci: Pakan buatan komersial, tepung bayam, kepiting bakau, sistem resirkulasi tertutup.

\begin{abstract}
This study aims to determine the effect of feeding with commercial diet (CD) contained spinach leaf meal (SM) feed on the growth and survival of mangrove crabs (S. serrate) reared in a closed recirculation system. This study used a completely randomized design (CRD) with 4 treatments and 3 replications. Four experimental diet were prepared by repelleting with different percentages of CD and SM. They were 55\% CD+40\% SM + 5\% CMC (Diet A), 50\% CD+ 45\% SM+ 5\% CMC (Diet B), 45\% CD+ 50\% SM + 5\% CMC (Diet C) and 40\% CD + 55\% SM + 5\% CMC (Diet D) and fed the mud crabs for 60 days of rearing. Some parameters observed were weight gain, specific growth rate (SGR) and survival rate (SR.). Results of analysis of variance showed that artificial feed with the addition of spinach flour were not significantly different (P> 0.05) in weight gain, SGR and SR that of the crabs for 60 days of rearing. The weight gain of the crabs were ranged between 17.3 to $22.3 \mathrm{~g}$, while specific growth rate of mud crabs were ranged between 0.0025 to $0.0038 \%$ and the survival rate of mud crabs is $100 \%$.. This study concluded that spinach leaf meal can be added to commercial feed around $40-50 \%$.
\end{abstract}

Keywords: Spinach flour, mangrove crabs, closed recirculation system ; repelleting.

\section{PENDAHULUAN}

Kepiting bakau merupakan salah satu komoditas perikanan yang bernilai ekonomis dan ekologis tinggi, hidup diperairan pantai, khususnya, dihutan bakau. Menurut Kementerian Kelautan dan Perikanan (2012), permintaan kepiting bakau terbesar hingga tahun 2011 adalah China, yang mencapai 4000 ton. Negara lain yang juga merupakan target ekspor kepiting bakau produksi indonesia antara lain Amerika serikat, kanada, Inggris, Belanda, Prancis dan Jerman. Tingginya nilai jual kepiting bakau, mendorong peningkatan laju eksploitasi yang mengarah pada metode penangkapan tidak bertanggung jawab oleh beberapa pihak. Laju eksploitasi ini dapat dilihat dari data statistik perikanan tangkap Kementerian Kelautan dan Perikanan (KKP) tahun 2008-2012, dari volume produksi kepiting bakau 26.628 ton pada tahun 2008 mengalami peningkatan menjadi 33.910 ton pada tahun 2012.

Salah satu cara mengatasi hal tersebut adalah dengan melakukan budidaya baik dalam pembenihan maupun pembesaran. Dalam usaha budidaya, pakan menyedot biaya tertinggi yaitu mencapai $60-80 \%$ dari total biaya produksi. 
Selama ini pakan yang digunakan dalam budidaya kepiting bakau ( $S$. serrata) yaitu pakan segar. Kendala yang dihadapi pada pakan tersebut bergantung pada musim (musiman), serta harga pakan yang relatif mahal. Oleh karena itu, dibutuhkan pakan yang dapat tersedia secara kontinyu, murah dan berkelanjutan yaitu dengan membuat pakan buatan dengan kandungan nutrisi yang dapat disesuaikan dengan kebutuhan kepiting bakau (S. serrata).Salah satu alternatif yang dilakukan untuk mempercepat moulting yaitu dengan menggunakan tepung daun bayam. Menurut Fujaya et al., (2008) bahwa penggunaan ekstrak bayam yang diberikan dengan cara penyuntikan kurang efisien dilakukan dalam skala besar. Upaya lain yang dapat dilakukan adalah dengan menggunakan pakan buatan sebagai media aplikasi ekstrak bayam atau tepung bayam. Berdasarkan uji yang telah dilakukan terbukti bahwa ekstrak bayam dapat diberikan melalui pakan buatan, danefektif mempercepat moulting dan meningkatkan pertumbuhan (Fujaya et al., 2009).

Kemudian degradasi ekosistem mangrove karena pemanfaatan lahan yang tidak bertanggung jawab, juga menjadi isu lain yang tidak kalah pentingnya karena sangat mempengaruhi stok kepiting bakau di habitatnya. Oleh karena itu, berbagai langkahlangkah perbaikan harus terus diupayakan yang mengarah pada praktik perikanan kepiting bakau yang bertanggung jawab dan berkelanjutan, salah satunya yaitu melakukan budidaya dengan sistem resirkulasi tertutup (Fauzzia et al., 2013). Resirkulasi merupakan salah satu sistem budidaya dalam proses produksi biota budidaya dengan sistem lingkungan dan keamanan yang terkontrol (Hastuti et al., 2017). Telah banyak dikembangkan sistem pemeliharaan kepiting bakau indoor dengan menggunakan sistem resirkulasi. Habitat yang sesuai untuk budidaya kepiting memiliki standar kualitas lingkungan diantaranya adalah suhu $25-35{ }^{\circ} \mathrm{C}, \mathrm{pH} 7,0-9,0$, DO lebih dari $5 \mathrm{mg} / \mathrm{L}$, dan kadar garam berkisar 10-30 g/L (FAO, 2011). Salah satu upaya peningkatan produksi budidaya dengan lingkungan terkontrol dengan sistem resirkulasi telah diterapkan di beberapa negara lainnya yaitu Singapura, Vietnam dan China. Sistem resirkulasi ini pada dasarnya merupakan proses filtrasi yang melewatkan air melalui media berpori (Dewi dan Masithoh, 2013). Sistem resirkulasi merupakan sistem yang memanfaatkan kembali air yang sudah digunakan dengan cara memutar air secara terus-menerus melalui perantara sebuah filter atau ke dalam wadah sehingga sistem ini bersifat hemat air (Sidik, 2002; Djokosetiyanto et al., 2006; Prayogo et al.,2012).

Berdasarkan penjelasan di atas, maka dilakukan penelitian tentang penggunaan tepung daun bayam dalam pakan buatan dengan tujuan mengetahui pengaruhnya terhadap pertumbuhan dan tingkat kelangsungan hidup kepiting bakau ( $S$. serrata) yang dipelihara pada system resirkulasi.

\section{BAHAN DAN METODE}

\section{Persiapan Hewan Uji dan Adaptasi}

Hewan uji yang digunakan dalam penelitian berasal dari pengepul yang diambil dari alam (ukuran $100 \mathrm{~g}$ ). Pengambilan hewan uji berasal dari daerah Bombana. Sebelum dilakukan pengamatan maka kepiting bakau terlebih dahulu di adaptasikan kedalam akuarium selama 1 minggu dengan asumsi kepiting bakau tidak lagi mengalami stress pada saat penelitian. Setelah tahap adaptasi, kepiting bakau ditimbang untuk mengatahui berat awal kepiting bakau sebelum pengamatan.

\section{Persiapan Wadah}

Wadah budidaya yang digunakan dalam penelitian ini adalah satu set rangkaian sistem reresirkulasi. Sistem reresirkulasi yang terdiri dari box dengan ukuran panjang $30 \mathrm{~cm}$, lebar $16 \mathrm{~cm}$ dan tinggi $12 \mathrm{~cm}$ berjumlah 12 unit yang di tempatkan dalam rak dengan susunan secara bertingkat dengan jumlah deretannya 4 unit menyamping dan 3 unit kearah atas. Penelitian ini menggunakan rancangan acak lengkap (RAL) yang terdiri dari 4 perlakuan dan 3 kali ulangan.

\section{Persiapan Pakan Uji}

Pakan buatan yang digunakan dalam penelitian ini dibuat dengan sistem repelleting, yaitu mencampurkan pellet pakan komersil (PK) dan tepung daun bayam (TB) dengan jumlah yang berbeda dan ditambahkan bahan pengikat/binder (CMC), perbandingan jumlah ini digunakan sebagai perlakuan penelitian, dimana perlakuan A $(55 \% \mathrm{PK}, 40 \% \mathrm{~TB}, 5 \%$ $\mathrm{CMC})$, perlakuan $\mathrm{B}(50 \% \mathrm{PK}, 45 \% \mathrm{~TB}, 5 \%$ CMC), perlakuan C (45\% PK, 50\% TB, 5\% 
CMC) dan perlakuan D (40\% PK, 55\% TB, 5\% CMC).

Proses pembuatan pakan dimulai dengan menimbang semua bahan pakan sesuai dengan jumlah pakan yang akan dibuat. Selanjutnya semua bahan tersebut dicampur hingga menjadi adonan kemudian dikukus dan dicetak menjadi pellet dan terakhir dijemur agar kadar air di dalam pellet berkurang.

\section{Pemberian Pakan}

Frekuensi pemberian pakan pada hewan uji dilakukan 2 kali sehari, pada jam 07.00 Wita dan 17.00 Wita. Pemberian pakan disesuaikan dengan berat hewan uji dengan persentase pakan yang diberikan sebanyak 5\% dari berat hewan uji per hari (Rathinam $d k k, .2009)$.

\section{Variabel yang Diamati}

\section{Pertumbuhan Mutlak}

Pertumbuhan mutlak dihitung dengan menggunakan rumus $\mathrm{Hu} d k k$. (2008), di bawah ini yaitu :

$$
\mathrm{PM}=\mathrm{Wt}-\mathrm{W} 0
$$

Dengan : $\mathrm{PM}=$ Pertumbuhan mutlak $(\mathrm{g}), \mathrm{Wt}=$ Bobot rata-rata kepiting pada akhir penelitian $(\mathrm{g})$ dan $\mathrm{W} 0=$ Bobot rata-rata kepiting pada awal penelitian $(\mathrm{g})$.

\section{Laju pertumbuhan spesifik}

Laju Pertumbuhan Spesifik (LPS) dihitung menggunakan rumus Zonneveld $d k k$. (1991), dibawah ini yaitu :

$$
\text { LPS }=\frac{\operatorname{Ln} \mathrm{W} t-\operatorname{Ln} \mathrm{Wo}}{\mathrm{t}} X 100 \%
$$

Dengan : LPS $=$ Laju pertumbuhan spesifik $(\%)$, $\mathrm{Wt}=$ Bobot rata-rata kepiting pada akhir penelitian (g), $\mathrm{W} 0=$ Bobot rata-rata kepiting pada awal penelitian $(\mathrm{g}), \mathrm{t}=$ Lama pemeliharaan (hari).

\section{Tingkat Kelangsungan Hidup}

Tingkat kelangsungan hidup kepiting uji dihitung dengan menggunakan rumus $\mathrm{Hu} d k k$. (2008), di bawah ini yaitu :

$$
\mathrm{SR}=\frac{\mathrm{Nt}}{\mathrm{No}} \mathrm{X} 100 \%
$$

Dengan : SR = Tingkat kelangsungan hidup (\%), $\mathrm{Nt}=$ Total kepiting pada akhir penelitian (ekor), No $=$ Total kepiting pada awal penelitian (ekor)

\section{HASIL}

\section{Pertumbuhan Mutlak (PM)}

Nilai rata-rata pertumbuhan Mutlak pada perlakuan A, B, C dan D secara berturut-turut sebesar,17,3 g,19,6 g, 20,7 g dan 22,3 g. Berdasarkan hasil analisa ragam menunjukkan bahwa, pakan uji memberi pengaruh yang tidak signifikan terhadap pertumbuhan mutlak kepiting bakau $(\mathrm{P}>0,05)$ (Gambar 1).

\section{Laju Pertumbuhan spesifik}

Nilai rata-rata Laju Pertumbuhan Spesifik pada perlakuan A, B, C dan D secara berturut-turut sebesar 0,003, 0,0025\%, $0,0034 \%$, dan $0,0038 \%$. Berdasarkan hasil analisa ragam menunjukkan bahwa, pakan uji memberi pengaruh yang tidak signifikan terhadap Laju Pertumbuhan Spesifikkepiting bakau $(\mathrm{P}>0,05)$ (Gambar 2).

\section{Kelangsungan Hidup}

Nilai rata-rata kelangsungan hidup kepiting bakau tinggi pada semua perlakuan sebesar $100 \%$. Hasil analisa ragam menunjukkan bahwa, pakan uji memberi pengaruh yang tidak signifikan terhadap kelangsungan hidup kepiting bakau $(\mathrm{P}>0,05)$ (Gambar 3).

\section{Kualitas air}

Hasil pengukuran kualitas air selama penelitian disajikan pada Tabel 1.

Tabel 1. Hasil pengukuran kualitas air pada media pemeliharaan selama penelitian.

\begin{tabular}{lll}
\hline Parameter & $\begin{array}{l}\text { Hasil } \\
\text { pengukuran }\end{array}$ & Nilai Optimal \\
\hline Suhu $\left({ }^{0} \mathrm{C}\right)$ & $28-29$ & $\begin{array}{l}23-32 \text { (Kordi dan } \\
\text { Tancung, 2007) }\end{array}$ \\
$\begin{array}{l}\text { Salinitas } \\
\text { ppt) }\end{array}$ & $28-33$ & 20-35 (Asih, 2008) \\
pH & 8 & $\begin{array}{l}8 \text { (Slamet dan } \\
\text { Imanto, 1989) }\end{array}$ \\
\hline
\end{tabular}




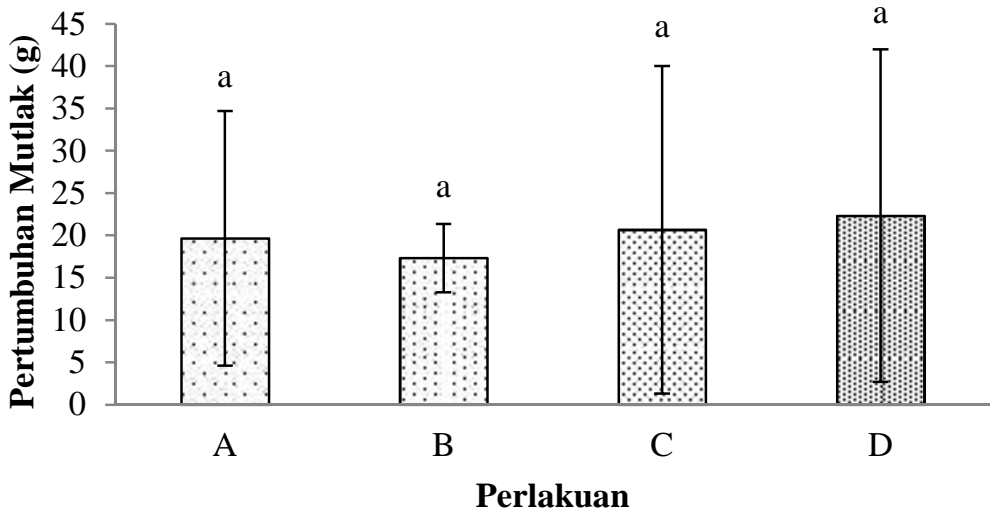

Gambar 1. Pertumbuhan Mutlak kepiting bakau yang diberi pakan buatan dengan tepung daun bayam. Keterangan: A (55\% PK, $40 \% \mathrm{~TB}, 5 \% \mathrm{CMC})$; B (50\% PK, $45 \% \mathrm{~TB}, 5 \% \mathrm{CMC})$; C (45\% PK, $50 \%$ $\mathrm{TB}, 5 \% \mathrm{CMC})$; dan $\mathrm{D}(40 \% \mathrm{PK}, 55 \% \mathrm{~TB}, 5 \% \mathrm{CMC}) .{ }^{\mathrm{a}}$ superscript yang sama menunjukkan tidak ada perbedaan signifikan pada taraf $\alpha=0,05$

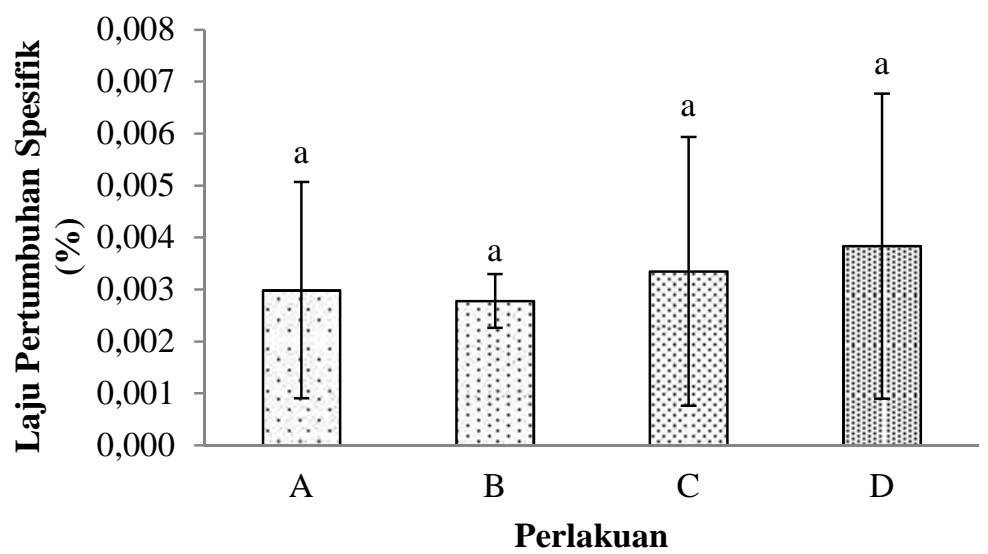

Gambar 2. Laju pertumbuhan spesifik kepiting bakau yang diberi pakan buatan dengan tepung daun bayam. Keterangan: A (55\% PK, 40\% TB, 5\% CMC); B (50\%PK, $45 \%$ TB, 5\% CMC); C (45\% PK, 50\% $\mathrm{TB}, 5 \% \mathrm{CMC})$; dan D (40\% PK, 55\% TB, 5\% CMC). ${ }^{\mathrm{a}}$ superscript yang sama menunjukkan tidak ada perbedaan signifikan pada taraf $\alpha=0,05$

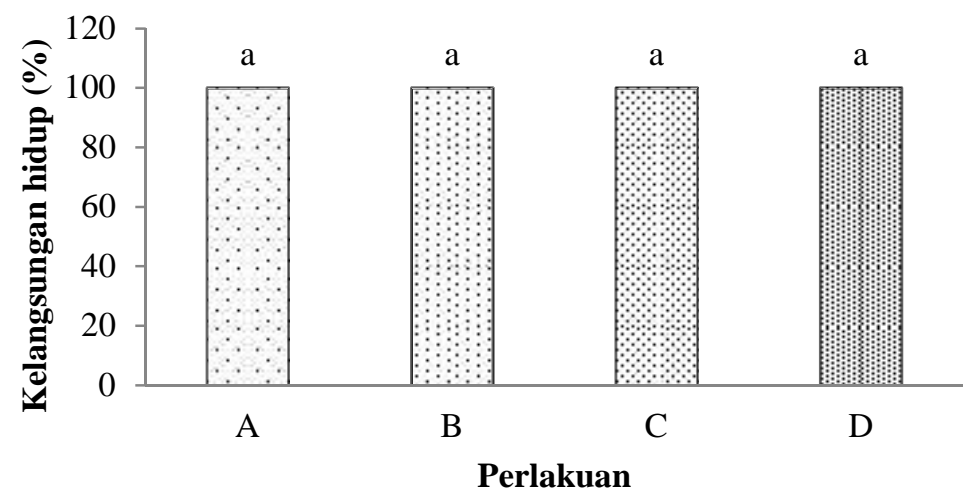

Gambar 3. Kelangsungan hidup kepiting bakau yang diberi pakan buatan dengan tepung daun bayam. Keterangan: A (55\% PK, $40 \%$ TB, 5\% CMC); B (50\%PK, $45 \%$ TB, 5\% CMC); C (45\% PK, $50 \%$ $\mathrm{TB}, 5 \% \mathrm{CMC})$; dan D (40\% PK, 55\% TB, 5\% CMC). ${ }^{\text {a }}$ superscript yang sama menunjukkan tidak ada perbedaan signifikan pada taraf $\alpha=0,05$ 


\section{PEMBAHASAN}

Berdasarkan hasil penelitian didapatkan, bahwa pakan buatan dengan penambahan bayam pada dosis $40-55 \%$ dengan range $5 \%$ antar tiap perlakuan memberikan respon yang tidak berbeda nyata terhadap pertumbuhan kepiting bakau. Cenderung tingginya nilai pertumbuhan pada perlakuan D (40\% PK, 55\% $\mathrm{TB}, 5 \% \mathrm{~B})$ yaitu 22,3g diasumsikan karena tingginya tepung bayam yang terdapat pada pakan tersebut, dimana bayam mengandung senyawa yang dapat merangsang pergantian kulit/molting. Range yang tidak terlalu jauh menyebabkan kadar dari pakan berupa protein terhadap pertumbuhan dan ekdisteroid terhadap molting memberi pengaruh yang tidak berbeda nyata (Bakrim dkk., 2008). Bayam mengandung ekdisteroid dimana merupakan hormon yang berperan dalam mengontrol moulting pada Arthropoda dan Crustacean (Fujaya dkk., 2012). Selain mengandung vitamin dan mineral, bayam mengandung senyawa kimia serupa dengan hormon moulting atau ekdisteroid pada Crustacea. Pada bayam dan tanaman lainnya, hormon ini berfungsi sebagai agen pertahanan diri dari serangan serangga atau cacing. Hasil penelitian yang dilakukan oleh (Prasetyo $d k k$., 2013) penambahan kombinasi air kapur dan bayam dengan berbagai konsentrasi pada pakan memberikan pengaruh yang berbeda terhadap durasi moulting kepiting uji. Durasi moulting paling singkat didapatkan pada formula A4B40 yaitu perlakuan dengan penambahan $4 \mathrm{ml}$ air kapur dan $40 \mathrm{~g}$ bayam pada pakan dengan ratarata 20 hari.

Menurut Meyer (2007) proses moulting dimulai ketika sel-sel epidermal merespons perubahan hormonal melalui laju sintesis protein. Peningkatan laju sintesis protein akibat rangsangan dari hormon moulting menyebabkan terjadinya apolisis (pemisahan secara fisik antara epidermis dengan endokutikula). Selanjutnya, selsel epidermal mengisi gap dengan larutan moulting inaktif dan kemudian menyekresi lipoprotein khusus atau lapisan kutikulin. Lapisan kutikulin akan menjadi bagian dari epikutikula baru. Setelah pembentukan lapisan kutikulin, larutan moulting menjadi aktif dan zat kimianya akan mencerna endokutikula dari eksoskeleton lama. Lapisan kutikulin akan memproduksi asam amino dan mikrofibril yang selanjutnya didaur ulang oleh sel-sel epidermal dan disekresi ke bawah lapisan kutikulin sebagai prokutikula baru yang lembut dan berkerut. Ketika eksoskeleton baru telah siap, kontraksi otot dan pengisian udara menyebabkan tubuh menggembung sehingga eksoskeleton lama retak sepanjang garis ecdysial sutures dan akhirnya tubuh dengan eksoskeleton baru keuar dari eksoskeleton lama. Setelah itu, eksoskeleton baru yang masih lembut dan berkerut akan terentang setelah terisi air sehingga ukuran kepiting bertambah setelah moulting.

Laju pertumbuhan yang didapat pada perlakuan B yaitu $0,003 \%$ cenderung lebih kecil dibandingkan degan perlakuan D yaitu $0,0038 \%$. Kecendrungan tersebut berdasarkan analisa ANOVA memberi pengaruh yang sama. Dikarenakan pakan yang dimakan kurang dimanfaatkan. Diduga karena lamanya pakan berada di air sehingga kandungan nutrisi pada pakan akan berkurang. Hal ini dipertegas oleh Tim Peneliti Balitbang Perikanan dan Kelautan Jawa Tengah (2005) yang mengatakan bahwa jenis pakan apabila berada dalam air terlalu lama maka akan diurai menjadi senyawasenyawa yang lebih kecil berupa asam-asam amino penyusunnya kemudian menghasilkan produk amoniak yang cukup berbahaya bagi kehidupan kepiting. Adanya perbedaan pertumbuhan laju pertumbuhan spesifik diduga karena kepiting bakau mempunyai sifat-sifat sendiri dalam hal pola kebiasaan makan dan makanannya. Pada waktu siang hari kepiting bakau pasif dan cenderung bersembunyi di balik batu karang, sedangkan pada malam hari kepiting bakau cenderung bergerak mencari makan (nokturnal) (Almada, 2001) Kecenderungan tingginya laju pertumbuhan spesifik pada perlakuan D yaitu $0,0038 \%$ mempuyai keseimbangan protein dan energy optimum. Satpathy et al. (2003) mengemukakan penggunaan protein maksimum untuk pertumbuhan berhubungan dengan pemasukan protein dan ketersediaan energi nonprotein, yaitu karbohidrat dan lemak. Pemasukan energi nonprotein memperlihatkan penghematan protein katabolisme untuk penyediaan energi dan meningkatkan protein untuk pertumbuhan, suatu proses yang dikenal dengan protein sparing effect. Satpathy et al. (2003) mengemukakan bahwa pakan dengan rasio protein per energi optimum akan 
menghasilkan pertumbuhan dan pemanfaatan pakan yang paling optimal. Peningkatan kadar protein pakan berakibat pada peningkatan pertumbuhan sampai batas tertentu pada kadar energi yang sama. Selanjutnya dijelaskan Jobling et al., (2001), Satpathy et al., (2003) bahwa pakan yang kandungan energinya kurang menyebabkan terjadinya penggunaan sebagian besar protein sebagai sumber energi. Sebaliknya jika kandungan energi pakan terlalu tinggi dapat menyebabkan pakan yang dimakan berkurang dan penerimaan nutrien lain termasuk protein yang diperlukan untuk pertumbuhan juga berkurang

Kelangsungan hidup menjadi salah satu peranan penting dalam kegiatan budidaya kepiting bakau. Menurut Boer (2000), kelang sungan hidup merupakan persentase populasi organisme yang hidup tiap periode waktu pemeliharaan tertentu. Berdasarkan hasil penelitian, sintasan/kelangsungan hidup kepiting bakau hewan uji tidak ada yang mengalami kematian (mortalitas) sehingga sintasan mencapai $100 \%$. Pakan yang diberikan memenuhi kebutuhan kepiting bakau dalam menunjang kehidupannya. Di dalam habitat alaminya kepiting bakau mengkonsumsi berbagai jenis pakan antara lain alga, daundaun yang telah membusuk, akar serta jenis kacang-kacangan, jenis siput, kodok, katak, daging kerang, udang, ikan, bangkai hewan sehingga kepiting bakau bersifat omnivora (Kasry, 1996).

Hasil pengamatan kualitas air selama penelitian (Tabel 3) diperoleh kisaran suhu sebesar $28-29^{\circ} \mathrm{C}$, kisaran suhu tersebut menunjukkan bahwa suhu air selama penelitian berlangsung, berada dalam kisaran yang optimal dalam artian kondisi suhu demikian memberikan kondisi lingkungan yang optimal bagi pertumbuhan dan kelangsungan hidup kepiting bakau (Scylla serrata). Pernyataan di atas sejalan dengan pernyataan Susanto (2009), yang menyatakan bahwa batas nilai toleransi suhu untuk kepiting bakau adalah sebesar 23$32^{\circ} \mathrm{C}$, selanjutnya Karim (2008), menyatakan bahwa suhu yang baik untuk kehidupan kepitingbakau adalah $24-32^{\circ} \mathrm{C}$. Selain itu menurut Boyd (1990), oksigen terlarut sangat esensial dibutuhkan oleh kepiting bakau untuk respirasi yang selanjutnya dimanfaatkan untuk kegiatan metabolism. Oleh sebab itu, kandungan oksigen terlarut harus selalu dipertahankan dalam kondisi optimum. Kisaran salinitas yang didapat sebesar 28-33\%o, pernyataan di atas didukung oleh hasil penelitian Susanto (2007), yang menyatakan bahwa, salinitas yang optimal untuk kehidupan kepiting bakau berkisar 15-32 ppt. Berdasarkan Ruscoe et al. (2014) melaporkan bahwa pertumbuhan maximum kepiting uji ( $S$. serrata) dicapai pada salinitas 10 ppt dan 20 ppt. Selanjutnya, Pedapoli dan Ramudu (2014) melaporkan bahwa pada salinitas $10 \mathrm{ppt}$, kepiting bakau memiliki laju pertumbuhan harian tertinggi (2,3 g/hari), sementara pada salinitas 29-30 ppt, kepiting bakau memiliki laju pertumbuhan harian terendah $(0,97-1,25$ $\mathrm{g} /$ hari).

Sedangkan kadar $\mathrm{pH}$ yang diperoleh selama penelitian adalah berkisar antara 7-8 hasil ini menunjukan kategori yang optimal, Rusdi dan Muhammad (2008) menyatakan bahwa bahwa $\mathrm{pH}$ yang optimum untuk kepiting bakau adalah berkisar antara 7,5-8,5. Menurut Kordi (1997), usaha budidaya perairan akan berhasil baik dengan $\mathrm{pH}$ 6,5-8,0 dan kisaran optimum adalah $\mathrm{pH} 7,5-8,7$. Pernyataan di atas dipertegas oleh Fujaya (2008), yang menyatakan bahwa kriteria lokasi yang ideal untuk pembudidayaan kepiting adalah daerah air payau atau air asin dengan kadar garam antara 15-35 ppt. Nilai $\mathrm{pH}$ air berkisar antara $7,2-7,8$. Suhu air yang ideal adalah $23-32^{\circ} \mathrm{C}$, dan lokasi memiliki jenis tanah liat berpasir dengan tipe dan tekstur tanah baik, ketersediaan pakan cukup, lokasi dekat dengan sarana dan prasarana produksi serta daerah pemasaran.

\section{KESIMPULAN}

Pemberian pakan buatan dengan penambahan tepung daun bayam memberi pengaruh yang tidak berbeda nyata terhadap pertumbuhan mutlak, laju pertumbuhan spesifik dan kelangsungan hidup kepiting bakau ( $S$. serrata) yang dipelihara selama 2 bulan.

\section{REFERENSI}

Almada. (2001). Studi tentang waktu makan dan jenis umpan yang disukai kepiting bakau (Scylla serrata). Skripsi. Program Studi Pemanfaatan Sumber Daya Perikanan, Fakultas Perikanan dan Ilmu Kelautan. Institut Pertanian Bogor. Bogor. 
Bakrim, A., Maria, A., Sayah, F., Lafont, R., \& Takvorian, N. (2008). Ecdysteroids in spinach (Spinacia oleracea L.): biosynthesis, transport and regulation of levels. Plant Physiology and Biochemistry, 46(10), 844-854.

Boer, Y. (2000). Uji aktivitas antioksidan ekstrak kulit buah kandis (Garcinia parvifolia Miq). Jurnal matematika dan IPA, 1(1): 26-33.

Boyd, C. E. (1990). Water Quality Management in Aquaculture and Fisheries Science. Elsevier Scientific Publishing Company. Amsterdam.

Dewi, Y. S. and M. Masithoh. (2013). The effectivity of biofiltration techniques with bio-ball media to decrease total nitrogen content. Journal Limit's, 9:4553.

Djokosetiyanto, D., Sunarma, A. dan Widanarni, (2006). Perubahan Ammonia (NH3-N), Nitrit (NO2-N) dan Nitrat (NO3-N) pada Media Pemeliharaan Ikan Nila Merah (Oreochromis Sp.) di dalam Sistem Reresirkulasi, Jurnal Akuakultur Ind., 5(1): 13-20.

FAO. (2011). Modul mud crab culture. Food and Agriculture Organization. Rome.

Fauzzia, M., Izza R. dan Nyoman W. (2013). Penyisihan Amoniak dan Kekeruhan pada Sistem Reresirkulasi Budidaya Kepiting dengan Teknologi Membran Biolfiter, Jurnal Teknologi Kimia dan Industri, Vol. 2 (2): 155-161.

Fujaya, Y., Aslamsyah S. Dan Usman Z. (2009). Respon Molting, Pertumbuhan, dan Mortalitas Kepiting Bakau (Scylla olivacea) yang Disuplementasi Vitomolt melalui Injeksi dan Pakan Buatan, Fakultas Ilmu Kelautan dan Perikanan Universitas Hasanuddin. Makassar.

Fujaya, Y., Aslamsyah S., Fudjaja L. dan Alam N. (2012). Budidaya dan Bisnis Kepiting Lunak, Stimulasi Molting dengan Ekstrak Bayam, Brilian Internasional, Surabaya.

Fujaya, Y., Trijuno, D. D. dan Suryati E, (2008). Pengembangan Teknologi Produksi Rajungan Lunak Hasil Pembenihan dengan Memanfaatkan Ekstrak Bayam sebagai Stimulan Molting. Laporan Penelitian Tahun II, RISTEK-Prog Insentif Riset Terapan,
MENRISTEK, Fakultas Ilmu Kelautan dan Perikanan. Universitas Hasanuddin. Makassar.

Hastuti, Y.P., K. Nirmala, I. Rusmana, R. Affandi, and W.B. Kuntari. (2017). Optimization of Stocking density in intensification of Mud crab Scylla serrata cultivation in the resirculation system. J. Akuakultur Indonesia. 16: 253-260.

Hu, Y., Tan, B., Mai, K., Ai, Q., Zheng, S., \& Cheng, K. (2008). Growth and body composition of juvenile white shrimp, Litopenaeus vannamei, fed different ratios of dietary protein to energy. Aquaculture Nutrition, 14(6), 499-506.

Karim, M. (2007). Pengaruh salinitas dan bobot terhadap konsumsi kepiting bakau Scylla serrata Forsskal. Jurnal Sains dan Teknologi, 7, 85-92.

Kasry, A. (1996). Budidaya Kepiting Bakau dan Biologi Ringkas. Bharata. Jakarta.

Kordi, M. G. \& Tanjung, A. B. (2007). Pengelolaan Kualitas Air dalam Budidaya Perairan. Rineka Cipta. Jakarta.

Kordi. (1997). Budidaya Air Payau. Penerbit Effhar dan Dahara Prize Jakarta Barat.

Meyer, J. R. (2007). Morphogenesis. Department of entomology NC State University. www.morphogenesis.com

Pedapoli, S., Ramudu, K. R. (2014). Effect of water quality parameters on growth and survivability of Mud Crab, Scylla tranquebarica, grow out at Kalimada Coast, Andra Pradesh. International Journal of Fisheries and Aquatic Studies, 2(2): 163-166.

Prasetyo, A. D. A., Hariyani, D., Kuswanti, N. (2013). Penambahan Air Kapur dan Bayam pada Pakan untuk Mempersingkat Durasi Moulting Kepiting Bakau (Scylla serrata) Jantan. LenteraBio: Berkala Ilmiah Biologi, 2(3): 271-278.

Prayogo, Y. (2012). Virulensi beberapa Isolat Cendawan Entomopatogen Beauveria Bassiana (Balsamo) Vuill. untuk Mengendalikan Penggerek Ubi Jalar Cylas formicarius. Prosiding. Seminar Nasional Hasil Penelitian Tanaman Aneka Kacang dan Umbi Tahun 2011. Pusat Penelitian dan Pengembangan 
Tanaman Pangan, Badan Penelitian dan Pengembangan Pertanian.

Rathinam, A. M. M., Kandasamy, D., Kizhakudan, J. K., Leslie, V. A., \& Gandhi, A. D. (2009). Effect of dietary protein on the growth of spiny lobster Panulirus homarus (Linnaeus). Journal of the Marine Biological Association of India, 51(1): 114-117.

Ruscoe IM, Shelley CC, Williams GR. 2014. The combined effects of temperature and salinity on growth and survival of juvenile mud crabs (Scylla serrata Forskål). Aquaculture 238:239-247.

Satpathy, B., Mukherjee B. D., Ray. A. K. (2003). Effect of dietary protein and lipid levels on growth, feed conversion and body composition in rohu Labeo rohita (Hamilton), Fingerlings. Aqua Nutr., 9: 17-24.

Sidik, A.S. (2002). Pengaruh Padat Penebaran Terhadap Laju Nitrifikasi dalam Budidaya Ikan Sistem Reresirkulasi Tertutup, Jurnal Akuakultur Indonesia, Vol. 1 (2).

Slamet, B. \& Imanto, P. T. (1989). Pengamatan Pemeliharaan Udang Karang (Peneaus homaus) di Laboratorium. Badan Pennelitian dan Pengembangan Pertanian. Balai Penelitian Budidaya Pantai. Maros.

Susanto, B. (2007). Pertumbuhan, Sintasan dan Keragaan Zoea Sampai Megalopa Rajungan (Portunus pelagicus) Melalui Penurunan Salinitas. Jurnal Perikanan Universitas Gadjah Mada, 9(1): 154-160.

Tim Peneliti Balitbang Perikanan dan Kelautan Jawa Tengah. (2005). Pembuatan Demplot Budidaya Kepiting Soft Cell sebagai Upaya Pemberdayaan Masyarakat Pesisir. Semarang.

Zonneveld, N., Huiman, E.A., Bonn, J. H. (1991). Budidaya Ikan. Gramedia. Jakarta. 